\title{
BUSINESS
}

\section{Biofuels bandwagon hits a rut}

\section{As politicians propose higher biofuel targets, soaring maize prices in the United States are putting new investment in ethanol production on hold. Lucy Odling-Smee reports.}

The scramble by investors in the United States to get into biofuels has caused a surge in production of the nation's main biofuel - cornbased ethanol - and pushed up the price of corn (maize). Theoretical concerns about competing demands for fuel and food are now economic reality.

Livestock farmers who use corn for animal feed are feeling the pinch of prices that have doubled since last year. And ethanol investors are waiting to see whether farmers can increase corn production in the coming season and pull costs back down.

"The question is, how quickly can both economic systems adjust?" asks Steve Bantz, a senior engineer with the clean-vehicles programme at the Union of Concerned Scientists (UCS), a liberal advocacy group in Washington DC.

The soaring price of corn is arguably unsurprising, given that ethanol-production capacity has nearly quadrupled since 2000 , to 21 billion litres ( 5.6 billion gallons). It is expected to double again in the near future if plans for new processing plants and the expansion of existing ones are followed through. The US ethanol industry is already expected to use up $20 \%$ of the country's corn crop this year, compared with $5 \%$ or less before 2000 .

The ethanol boom stems from converging economic and political forces. The price of oil has been relatively high in recent years, and energy security and independence have emerged as a political issue. As part of a

\section{"US farmers will} probably plant one of the largest corn crops on record this year."

\section{- Brian Jennings}

banned MTBE after reports that it poses a health risk. Phasing it out has left a 7.5-billionlitre hole for ethanol to fill.

All these factors have lured investors, including major agribusinesses such as Archer Daniels Midland (ADM), based in Decatur, Illinois, and Cargill, headquartered in Minneapolis, Minnesota. ADM alone accounts for one-fifth of US ethanol production - and the company has plans to expand that by more than $25 \%$. More than 100 other companies, many privately held, have also come on board.

However, for companies that haven't yet put their money on a law enacted by Congress in 2005 requires 28 billion litres ( 7.5 billion gallons) of the nation's fuel to come from ethanol and biodiesel by 2012. On 4 January, five Democratic senators introduced the Biofuels Security Act of 2007, which would raise this to 227 billion litres.

A 51-cent tax credit currently goes to buyers for every gallon of ethanol they mix with petrol. The industry is also protected from foreign competition by a hefty export tariff of 54 cents per gallon on imported ethanol.

Renewable-energy analysts say, however, that the most important driver of the surge in ethanol production has been its use as a substitute for methyl-t-butyl ether (MTBE) - an additive used to make petrol meet emissions requirements. Scores of states have recently ethanol, investments that looked rosy several years ago are beginning to lose their shine. Corn prices that stand at $\$ 162$ per tonne $(\$ 4.10$ a bushel), up from $\$ 79$ last year, aren't the only deterrent: costs of building materials are rising, and qualified engineers and technicians are scarce.

"The bloom is off the rose," says Ben Lieberman, a policy analyst at the Heritage Foundation, a conservative think tank in Washington DC.

Brian Jennings, executive vice-president of an ethanol-advocacy group, the American Coalition for Ethanol, in Sioux Falls, South Dakota, says that in the past two months he has been contacted by a dozen companies that have decided not to take their projects forward because of market conditions.
Ethanol-advocacy groups are confident that the market for corn will recalibrate, however, with farmers turning to other feed for their livestock, and planting corn on land not used for the crop before. "US farmers will probably plant one of the largest corn crops on record this year," predicts Jennings.

This prospect makes environmentalists worry that the biofuels industry will stress not only the food economy but also the environment. Using more marginal land could mean more fertilizers, more irrigation and more pesticides, says Bantz. The real problem, he adds, is the rate at which the ethanol industry has taken off - before a proper analysis to quantify the advantages and disadvantages, in terms of energy obtained and emissions released, of biofuels made from different starting materials.

Bantz and others contend that, for ethanol to become a serious player in helping the United States reduce its reliance on petrol, a slower pace may be crucial - in part to allow technological developments such as genetically modified corn that gives a higher ethanol yield or the scaling up of ethanol production from non-food sources such as switchgrass or sawdust.

According to Barbara Bramble of the Washington-based National Wildlife Federation, the United States may have something to learn from Europe. There, she says, the industry is developing slowly enough to allow appropriate adjustments in land use and technology to be made. 